\title{
Preventive Measures for Corruption Through Anti-Corruption Education at Higher Education Institution (A Case Study at State Polytechnic of Malang )
}

\author{
Sri Hudiarini \\ Lecturer in State Polytechnique of Malang, Indonesia \\ Soekarno Hatta Street No. 9, Malang, 65141
}

\begin{abstract}
High level of corruption gives Indonesia adverse image among international communities. It may brings disadvantageous impact for various sectors. Effort of corruption eradication has so far focused on two aspects namely prevention and prosecution of corruption. The two measures will gives satisfying result if government bodies and society work together. To prevent corruption, there is a need for active participation of students by developing anti-corruption culture in our society. This study aims at encouraging university students to take active role as agent of change and pioneer for anti-corruption movements. For students of State Polytechnique of Malang, This is quantitative study by employing descriptive approach aiming at elaborating or describing events, circumstances, people or other objects which are interrelated. Data are gathered by conducting interview, observation and distributing questionnaire. For students of State Polytechnique of Malang, anti-corruption education aims at giving sufficient knowledge on corruption and its eradication efforts as well as internalizing values of anti-corruption. In addition, it also aims at developing anti-corruption culture and encouraging students to take active role in preventive measure for corruption in Indonesia.Based on several previous studies, the researcher comes to conclusion that anti-corruption education, which is part of Pancasila and Citizenship Education, might develop students' awareness to prevent corruption. It is expected that after graduating from State Polytechnique of Malang, they are able to put themselves as role model for people around them. On the other side, there are several instructional method used in State Polytechnique of Malang. Those are In Class Discussion, Case Study, Thematic exploration, Film Discussion and General Lecture.
\end{abstract}

Keywords: preventive measures, anti-corruption education, students, higher education.

DOI: $10.7176 / \mathrm{JLPG} / 105-11$

Publication date: January $31^{\text {st }} 2021$

\section{Introduction}

Indonesia, as member of world communities are known for its high level of corruption. It results in negative image and loosing trust from other countries. Foreign businessmen do not trust on bureaucracy in Indonesia and it makes them relocate their business to our neighbouring countries. This condition is disadvantageous for all aspect of live. Therefore, corruption might be called as "social parasite" damaging government structure and causing problem for national development. It seems that it is impossible to eradicate corruption because it needs numerous concrete evidences and involves many parties.

Government of Indonesia has conducted efforts to eradicate corruption. One of them is by establishing Corruption Eradication Commission in 2002 under Law no 30 of 2002. It is an independent government body specializing in eradicating corruptions by preventing and prosecuting them. Corruption is an extraordinary crime that needs extraordinary effort to eradicate.

Corruption eradication efforts consist of two tasks, namely prevention and prosecution task which might not be successful without people's participation. Therefore, students of higher education should take part in corruption eradication efforts in Indonesia.

We cannot solely rely on law officers to fight against corruption. Students as well as university faculty should take part in efforts of early prevention of corruption. Education is a media to educate future generation to prevent corruption. As future generation, students should give contribution for their people and nation. One of long term solution for corruption eradication is by conducting anti-corruption education to students of higher education. It is because the students will take over the position of today's government officials.

In addition, the youths are still vulnerable of influence from others. therefore, it will be easier to educate the youths in order to prevent them from corruption habits of their previous generation.

The youths are conscious to fight against and transform unrighteous condition. In our history, students took part in national struggle and national leaders usually arise from youth movement. Before independence, it was the youth who spearheaded Indonesian struggle against Dutch colonialism.

The afore-mentioned information are what students have done to maintain their idealism to fight against unrighteous condition. In this present era, students face even more formidable challenges than those in the past. It is corruption that should be eradicated for causing adverse condition in Indonesia. students should believe that 
corruption is common enemy to must be eradicated.

Students' involvement in corruption eradication efforts is not on the prosecution domain. It is expected that students take more active role in preventing corruption by setting up anti-corruption culture among their community. Students should be an agent of change and driving force for anti-corruption movement in society. Therefore, they should have sufficient knowledge on corruption and strategies to eradicate it.

Anti-corruption education for students aims at transferring sufficient knowledge on corruption and its eradication efforts, at encouraging students to take active role in preventing corruption, at internalizing values of anti-corruption and at developing anti-corruption culture among students. Universities which are responsible for producing high quality graduates have high concerns on anti-corruption education. Such kind of education facilitates students to understand corruption and prevent them to do corruption.

Research problems in this study are concerned with the function of anti-corruption education to arise students' awareness as preventive efforts to prevent corruption and with the model of anti-corruption education at State Polytechnique of Malang.

This is quantitative study which is a process of obtaining knowledge by using numerical data to analyse information on what is being studied. Kasiram (2008:149) in his book entitled Qualitative and Quantitative Research Methodology. The objective of quantitative research is to build nomothetic science which aims at formulating laws from its generalization. Subject of study, data and data sources as well as data collecting instruments are those that have been planned by researcher.

Because students are the subject of this study, then selection of methodology should employ descriptive approach. Punaji (2010) states that descriptive research is a study aims at explaining or describing events, circumstances, object, human object or others related to variables of study by using numerical data or description data.

According to Hidayat Syah, descriptive study is a research methodology used to finding out knowledge on research object at certain period of time. Data sources used are either primary sources in the form of subject of study and secondary data in the form of students' attendance list and underlying theories.

Data were gathered by interview and questionnaires. The data were then analysed in order to answer studied phenomenon in the form of numbers.

\section{Literature Review}

2.1 Anti-Corruption Education

Indonesian Dictionary states that definition of corruption is “evasion or fraud of government's or company's fund for personal gain”. Law no 31 of 1991 jo Law no 20 of 2001 also states that corruption is unlawful act for the sake of benefit of oneself, others or corporation causing loss on state fund or economics".

Corruption leads a state into bankruptcy because it causes damage on economics, education system and health service.

Quoting David M Chalmers, Baharudin Lopa said that corruption deals with bribery and manipulation in economic sector and also other public sector. It was taken from corruption definition which is "financial manipulation and depiction injurious to the economy are often labelled corrupt" (Evi Hartanti; 2008).

Anti-corruption education is conscious and planned effort to realize critical teaching and learning process for anti-corruption values. Therefore, anti-corruption education is not solely media for knowledge transfer (cognitive) but also for building positive character (affective) and moral awareness to fight against (psychomotor) distorted behaviour related to corruption.

Directorate general of higher education states that the objectives of anti-corruption education at higher education is to nurture anti-corruption habit on students and to encourage students to function as agent of change who are able to give positive contribution for the people and country. Standards of competence to achieve are that students should be able to

(1) Prevent themselves from doing corruption (individual competence). This individual competence facilitates students to internalize negative mindset on corruption and positive one on anti-corruption, and to improve their awareness on various kinds of corruption act. Students should build anti-corruption attitude that prevent them to conduct even trivial kind of corruption.

(2) Prevent others from doing corruption by giving various kinds of warning. This anti-corruption attitude will spread to their surroundings; students should have courage to warn or stop other people doing any kind of corruption and be able to give information on corruption and anti-corruption efforts.

(3) Detect possible effort of corruption students of higher education should be able to detect corruption from its type, process, rules broken, corruptor, and its damage/loss. Then, students should also be able to give solution (problem solving).

Essentially, Anti-corruption education is part of character building education focusing on nurturing values of community life. Our founding father of education, Ki Hajar Dewantara stated that education is efforts to develop moral virtues (character), mind (intellect) and body of students. Those part should not be separated for the sake of 
perfection of children life. The objective or learning outcome of anti-corruption education in higher education, which is in line with mission of Corruption Eradication Commission is to break chain of corruption in Indonesia. The rationale of anti-corruption education ((http://probopribadisembiringmeliala.blogspot.com) are

a. Corruption has been an accute problems in Indonesia. it could'nt be tackled by law enforcement only.

b. According to Paulo Freire, education is a way leading to permanent freedom in order that people are aware about oppression upon them. Therefore, there is a need for cultural action to free them from the oppression.

c. Fight against corruption is not effective and there has not been anti-corruption education.

\subsection{Factors Causing Corruption}

Erry Riyana Hardjapamekas (2008) states that there are several factors causing high level of corruption in Indonesia. Those are (1) lack of role model and leadership from national leaders, (2) low salary of government employees, (3) weak commitment on consistent law enforcement and implementation, (4) low integrity and professionalism, (5) no established internal mechanism at banking, financial institution and beureaucracy, (6)work condition, task and surrounding community and (7) lack of faith, honesty, moral and ethics.

In addition, Susila (in Hamzah, 2004) states that corruption is caused by weaknesses on regulations in which there are rules giving advantages on certain group of people, insufficient regulation and lack of socialization, light level of punishment, inconsistent application of punishment, lack of evaluation and revision on prevailing regulation.

Based on theory put forward by Kack Bologne which is called GONE Theory, it is stated that factors causing corruption are:

a. Greed: it is related to potentials greed in everyone.

b. Opportunities: it concerns with condition of organization or communities giving a chance for corruption.

c. Needs: it concerns with factors needed by individuals to live their life.

d. Exposures: it concerns with action or consequence faced by corruptors.

Concerning individual behavior, Isa Wahyudi elaborates that the causes of corruption are internal drive. It is willingness or intention to corrupt. Furthermore, the causes of corruption are: (a) human greeds, (b) weak morality, (c) consumptive life, (d) laziness to work (Isa Wahyudi: 2007).

\subsection{Strategies and eradication of corruption}

G. Peter Hoefnagels differentiates efforts to eradicate corruption or the called criminal policy into three. They are criminal law application, prevention without punishment, and influencing views of society on crime and punishment/mass media (Nawawi Arief: 2008).

According to Baharudin Lopa, preventing corruption is not hard if we are aware to put public interest more than private interest. It is crucial because no matter how perfect our regulation is, corruption will occur because people mental state is determinant factor. To analyse corruption, there are three strategies to prevent or to eradicate corruption. Those are

1) Preventive strategy

It is implemented by focusing on factors causing corruption.

2) Deductive strategy

This strategy is formulated and implemented in order to detect early potentials corruption.

3) Repressive strategy

It is formulated and implemented in order to give proportional punishment fastly and accurately to those involved in corruption. Therefore, criminal law is one way to eradicate corruption.

\subsection{Role and Involvements of Students of Higher University}

In Indonesia history, students of higher education has crucial role. It was started in 1908 of Indonesian National Awakening, in 1928 of Indonesian Youth Pledge, in 1945 of Indonesian Independence Day, in 1966 of the birth of New Order era and 1998 of the birth of Reformation order. They are driving force of those occasion with their ideas, spirit and idealism.

Having high intellectual ability, spiritful enthusiasm, and pure idealism, students always take significant role in national history. Students are agent of change which has been proven. Thus, students are also expected to be driving force for anti-corruption movements because they are equipped with special basic competence such as, intelligence, critical thinking skills, and courage to speak the truth.

The role of youth in corruption eradication is crucial in Indonesia. Therefore, they should take active role in national development process especially corruption eradication program in order to realize Indonesia which are free from corruption and prosperous. Education is inseparable part of corruption eradication efforts in Indonesia. It is because anti-corruption character might only be developed through education. In this context, the youth might take role in corruption eradication by their studying hard and implementing their knowledge for their life.

The benefit of education might be implemented early such as by conducting social activities in the form of 
collective work for society or demonstration to speak people aspiration. Thus, the youth might give contribution for our country in line with their function as agent of change. Character education is one of important kind of education for us.

There are two kinds of students' involvement in anti-corruption movement at university. The first concerns with students themselves and the second with students' community. For individual context, it is expected that students are able to keep themselves away from corruptive behaviour and corruption. For community context, it is expected that students might prevent their peers from corruptive action or even corruption. In order to take part in anti-corruption movements, students should show anti-corruptive behaviour. Therefore, students are able to internalize anti-corruption virtues and understand corruption and principles of anti-corruption movement. The virtues might be developed by joining seminar, campaign and course on anti-corruption. The values and knowledge should be implemented at their life. In other words, students should be able to show that they are free from corruptive behaviour.

\section{Discussion}

Agus Wibowo states that anti-corruption education is conscious and planned efforts to create critical teaching learning process on anti-corruption values. Anti-corruption education is not only knowledge transfer media (cognitive) but also character building (affective) and moral awareness to fight against corruption (psychomotor) (Wibowo,2 013;38).

Thus, we come to conclusion that anti-corruption education is conscious effort to develop awareness and to prevent corruption through formal or nonformal education. The objective of anti-corruption education is transformation of behaviour and attitude toward corruptive act, to develop awareness on the danger of corruption and to arouse willingness to fight against it.

Anti-corruption education is also intended to promote honesty, persistence to fight against corruption. Anticorruption education should be managed in the form of dialogue in order to create collective awareness on the significance of eradication and prevention of corruption. Policy to implement anti-corruption education is new awareness to develop anti-corruption behaviour since early stages.

The ultimate objective is to develop resistance culture against corruption which is started from family in order to create deterrent effect, to develop shameful culture, to create honesty values, culture of being responsible and to prevent corruption.

To gather data, the researcher formulates several question. The questions which are based on research questions are delivered to either students or lecturers.

The respondents are free to express their personal problems directly rather than stick on the questions from the researcher. Then, the researcher takes several explanations from the respondents for analysis.

The respondents are required to fill online link given to them. Main requirements to obtain accurate data are that respondents should answer the question honestly. Therefore, the researcher encourages them to answer the question honestly as reflected in introductory statements of questionnaire.

This study requires concrete data taken directly from respondents who are students of State Polytechnique of Malang.

There are 200 students filling out the questionnaires. The findings are shown in the form of diagram below

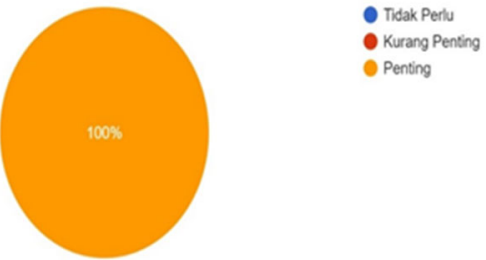

The findings show that $100 \%$ or all students of State Polytechnique of Malang states that anti-corruption education is crucial to be given in State Polytechnique of Malang.

Therefore, there is a need to create a sense of belonging to the institution as if it is their second home. Campus is intended to be a place for students to study freely and to give contribution without limitation. In addition, students might be given a chance to collect donation for those who need financial supports.

It will improve the quality of students relation. Other action that might be conducted is to give access for students to reach for their lecturers after school hour by using internet and to improves lecturers' role as facilitator and motivator. It is crucial for students to develop simple and economical way of life. Therefore, students should prioritize what they need more than what they want. Developing courage is also crucial because it will make 
students to be able to find solution for their problem.

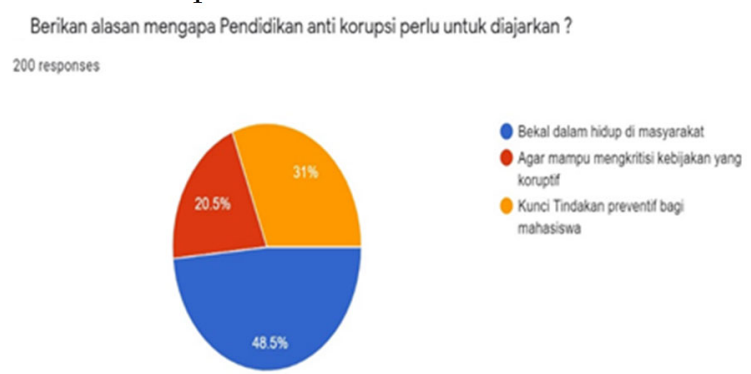

From the figure presented above, we know that the reasons why anti-corruption education is crucial for the respondents are

- $\quad 48,5 \%$ states that anti-corruption education it will give them what they need in the future.

- $20,5 \%$ states that they hope to be able to criticize policies on corruption.

- $31 \%$ states it anti-corruption corruption is preventive key for them.

Students' role are crucial because they have idealism and high intellectualism. The two facilitates students to take important role for our nation. History shows that students are crucial for agent of change.

The result of anti-corruption education is character transformation. It is of course positive transformation. Those who corrupts chooses to stop after joining anti-corruption education. It is expected that students do not corrupt at their work later.

Concerning their daily life, it is expected that students function themselves to be driving factors with their intelligence, critical thinking skills and courage to speak for the truth. There are two domains for students involvements in anti-corruption movement. The domains are the one related to students themselves and the other related to students community. For individual context, students should be able to prevent themselves from corruption.

For students' community, students are expected to keep their peers and students organization away from corruption.

Therefore, students should have character of anti-corruption and its principles. Socialization, campaign, seminar, workshop and other activities are useful for developing anti-corruption culture. For instance, a campaign not to cheat is a way to develop anti-corruption behavior. Developing virtues of hard working, honesty and responsibility is also significant. Kantin Kejujuran is another example of how to develop honesty and responsibility.
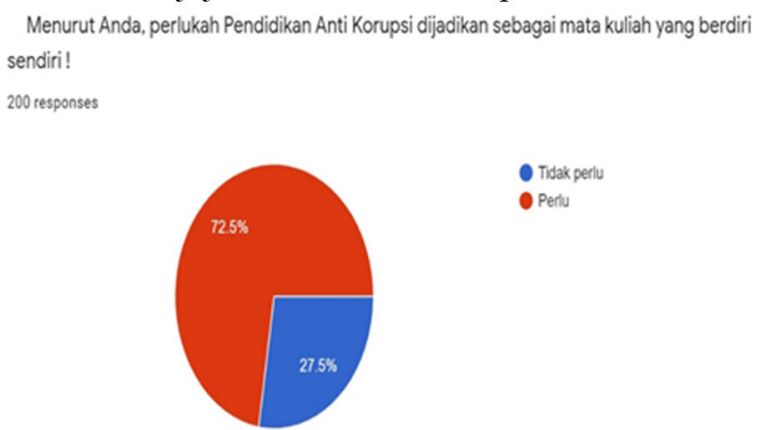

From the survey presented on the figure above, we find out the students' opinion on the significance of anticorruption education course which is separated from Civic Education. The percentages are

- $\quad 72,5$ students believe that it is not necessary to be one independent course.

- $\quad 27,5 \%$ students believe that it must be independent course.

The anti-corruption education aims at developing critical attitude toward corruption. After taking anticorruption course, students are able to recognize the danger of corruption. It will ruin national economy. Corruption prevents the achievement of economic goals. It also reduces public trust resulting in low investment because investors concerns to invest their fund.

Regarding book entitled Anti-corruption Education for Higher University, course materials are Definition of Corruption, Factors Causing Corruption, Massive Impact of Corruption, International Cooperation and Instruments of Corruption Prevention, Regulation of Corruption and Students' Role in Anti-corruption Movements.

There is no fixed arrangement for assessment of students' achievement for anti-corruption education course. The institution applying anti-corruption education course have authority for assessment. However, assessment for students' achievement aim at measuring learning achievement in the form of individual or group task, selfassessment, peer assessment, oral or written performance observation.

Corruption in Indonesia is so severe that it creates skepticism for all including students. Therefore, there 
should be new design for anti-corruption education to make it attractive and effective. Course materials are important but the choice of creative instructional method is key to optimize quality of lesson and to create critical thinking and integrity ethics on the part of students. Lecturers should be communicator, facilitator and motivator for students. Directors of institution should also take part in creating campus as land of integrity to support the effectiveness of anti-corruption corruption education.

Concerning the characteristics of instructional system in State Polytechnique of Malang, instructional model of anti-corruption education should be integrated with outside instruction. Classroom instruction is not necessary to be one independent course. Curriculum model and its instruction is integrated into existing and relevant course in the form of character-building education under Personality Development Courses namely Religious Education, Pancasila and Civic Education. Outside-classroom instruction might be in the form of developing students' potentials to explore and find out reality of life and its problem. Through outside-classroom instruction, students are trained to find solution for anti-corruption problems. Developing anti-corruption values will be meaningful and useful if students recognize and find them directly. Campus might be empowered by coordinating with Students' Organization and other relevant students' organization in State Polytechnique of Malang. Imperative and normative policies from institution management are also crucial to encourage discipline, responsibility and honesty. Therefore, organization culture will be developed in such a way that supports anti-corruption movements. Instructional model of anti-corruption might also be visualized into pictures of character building education. By anti-corruption education, it is expected that individual will have integrity. Role model emerges from lecturers, director of institution and other.

Anti-corruption education is not one independent course in State Polytechnique of Malang. It is integrated in Pancasila and Civic Education course. Instructional methods that might be used as

1. In class discussion. It is class discussion. Lectures discusses concepts of corruption and anti-corruption. It aims at developing awareness and building students' framework.

2. Case study. It discusses latest cases on corruption focusing on causes of corruption and its impact and anticorruption movement conducted by government or society.

3. Thematic exploration. In this instructional method, students are divided into groups to observe certain case of corruption or corruptive behaviour from various point of view such as socio cultural, economic or law point of view.

4. Film discussion. Film is used as visual media for instruction.

5. General lecture. It is conducted by inviting or presenting expert for experience sharing.

Selection of instructional method is crucial for presenting anti-corruption course. Teaching learning process will be effective if appropriate strategies of methods are employed. Inappropriate method or strategy of instruction will create boring situation and students will not be able to take the information in properly.

\section{Conclusion and Recommencation}

From the study conducted, the researcher draws conclusion that anti-corruption education which is part of Pancasila and Civic Education course should be able to arouse students' awareness as preventive action for corruption. It is expected that after finishing their study, students could be role model for people around them by using their knowledge obtained at university. Instructional models that might be implemented at State Polytechnique of Malang are In Class Discussion, Case Study, Thematic Exploration, Film Discussion, and General Lecture.

Anti-corruption education is early step to prevent future corruption. Students are able to recognize the danger of corruption. Anti-corruption course materials should be upgraded into independent compulsory course for all students of State Polytechnique of Malang. In addition, there must be example and role model from lecturers to implement anti-corruption culture.

\section{References}

Agus Wibowo. (2013), Pendidikan Antikorupsi di Sekolah Strategi Internalisasi Pendidikan Antikorupsi di Sekolah. Yogjakarta: Pustaka Pelajar.

Darmawan, Deni. (2013), Metode Penelitian Kuantitatif. Bandung: PT Remaja Rosdakarya.

Hartanti, Evi. (2008), Tindak Pidana Korupsi, Jakarta : Sinar Grafika

Hudiarini, Sri. dkk, (2018), Pendidikan Pancasila, Aditya Media, Yogyakarta

Jack Bologna, Tommie Singleton. (2006), Fraud Auditing And Forensic Accounting New Jersey : John Wiliey \& Sons Ink

Kasiram, Mohammad. (2008), Metode Penelitian Kuantitatif-Kualitatif. Malang:UIN Malang Press.

Punaji, Setyosari. (2010), Metode Penelitian Pendidikan dan Pengembangan. Jakarta Kencan

Sugiyono. (2013), Metode Penelitian Kuantitatif, Kualitatif dan R\&D, Bandung: Alfabeta

Jurnal

Arfan Faiz Muhlizi. (2014), Revolusi Mental Untuk Membentuk Budaya Hukum Anti Korupsi, Rechtsvinding 
Astika Nurul Hidayah. (2018), Analisis Aspek Hukum Tindak Pidana Korupsi Dalam Rangka Pendidikan Anti Korupsi, Kosmik Hukum

Ahmad Fikri Hadin dan Reja Fahlevi. (2016), Desain Bahan Ajar Pendidikan Kewarganegaraan Berbasis Pendidikan Anti Korupsi Di Perguruan Tinggi, Moral Kemasyarakatan, hal 162 sd 172

Asep Syarifuddin Hidayat. (2019), Pendidikan Kampus Sebagai Media Penanaman Nilai-nilai Antikorupsi Bagi Mahasiswa, Sosial Dan Budaya Syar'I, hal 43 sd 54

N.S. Junaedi, Ita Susanti, Sumiyati, Model Pembelajaran Pendidikan Anti Korupsi Di Lingk Politeknik Negeri Bandung ,file://C:/Users/hp/Downloads/844-Article\%20Text-1649-1-1020170928\%20(3).pdf, diakses 10 agustus 2020

Natal Kristiono. (2018), Penanaman Nilai AntiKorupsi Bagi Mahasiswa FIS UNES Melalui Mata Kuliah Pendidikan Anti Korupsi, Refleksi Edukatika, hal 40 sd 45.

Ita Suryani. (2015), Penanaman Nilai Nilai Anti Korupsi Di Lembaga Pendidikan Perguruan Tinggi Sebagai Pencegahan Preventif, Visi Komunikasi, hal 285 sd 301

Putra Perdana Saifullah. (2017), Peran Perguruan Tinggi Dalam Menumbuhkan Budaya Anti Korupsi, Hukum Dan Pembangunan.

Sutrisno. (2017), Implementasi pendidikan antikorupsi pada mata pelajaran PPKn berbasis project citizen di Sekolah Menengah Atas, Civic http://id.portalgaruda.org/article.php?article=435720\&val=9230, diakses 11 agustus 2020 